\title{
A Comparison of Event Framing in OLd Chinese AND OLD JAPANESE
}

\author{
Wenchao LI
}

Graduate of international cultural studies, Tohoku University, Japan

wideliau@gmail.com

\begin{abstract}
This paper brings data on Old Chinese and Old Japanese together in order to conduct an investigation into event-framing strategies. Old Chinese consists of a monosyllabic root with five constituents that express the path: (a) particle, (b) incorporated noun, (c) preverb, (d) verb root, and (e) complement. Verb framing, satellite framing, and equipollent framing are all found in the data. Crucially, before the birth of disyllabic word roots and verb compounding in the Late Han Dynasty, verb framing seems to have been the main pattern. Throughout the transformation of the Chinese language, the use of incorporated nouns and preverbs denoting the path has declined, with the remaining particles serving motion events. This contributes to the contention that contemporary Chinese is a satellite-framed language. Meanwhile, verb complements emerged and played the main role in non-motion events. In terms of Old Japanese, all three event-framing patterns have been observed. Moreover, the path is denoted via three means: prefix, auxiliary, and verb compounding. Among them, verb compounding appears to play the most significant role. These distinct event-framing patterns both intralinguistic and crosslinguistic are based on the diversity of lexical resources of motion/nonmotion event framing and preferences for event-encoding options by selecting different lexical resources.
\end{abstract}

\section{Keywords}

Old Chinese, Old Japanese, Event framing, Path, Manner

\section{Izvleček}

Članek proučuje strategije uokvirjanja dogodkov na osnovi gradiv iz stare kitajščine in japonščine. Staro kitajščino sestavlja pet tipov enozložnih korenov, ki izražajo sled: (a) členek, (b) inkorporirani samostalnik, (c) predglagol, (d) glagolski koren ter (e) dopolnilo. V gradivu je mogoče najti uokvirjanje $\mathrm{s}$ pomočjo glagolov, uokvirjanje s pomočjo satelitov kot tudi uokvirjanje s pomočjo obojih (equipollent framing). Kar je pomembno, pred rojstvom dvozložnih besednih korenov in sestavljenih glagolov v obdobju Poznega Hana je kot kaže kot glavni tip prevladovalo uokvirjanje s pomočjo glagolov. Skozi ves proces preoblikovanja kitajskega jezika je raba inkorporiranih samostalnikov za izražanje sledi in predglagolov za izražanje načina nazadovala; ostali členki so služili za izražanje dogodkov povezanih z gibanjem. Vse to je prispevalo $\mathrm{k}$ mnenju, da je sodobna kitajščina jezik, ki temelji na uokvirjanju s pomočjo satelitov. Nasprotno pa so se glagolska dopolnila pojavila in igrala glavno vlogo $\mathrm{v}$ dogodkih, ki niso povezani $\mathrm{z}$ gibanjem. V okviru stare japonščine so bili opaženi vsi trije tipi uokvirjanja. Sled se povrhu izraža s pomočjo treh sredstev: predpon, 
pomožnih glagolov in sestavljenih glagolov. Ti razločni vzorci uokvirjanja dogodkov, tako znotraj enega jezika kot medjezikovno, temeljijo na raznolikosti leksikalnih sredstev za uokvirjanje dogodkov, tako tistih, ki so povezani z gibanjem, kot tistih, ki niso, ter na prednostnem redu pri izboru različnih leksikalnih sredstev za kodiranje dogodkov.

\section{Ključne besede}

Stara kitajščina, Stara japonščina, uokvirjanje dogodkov, sled, način

\section{Introduction}

In Talmy's typological classification of complex events, all languages fall into two types: verb-framed languages and satellite-framed languages. Satellite-framed languages are languages that habitually map the core schema onto "satellites", such as prefixes, adverbs, and complements, whilst verb-framed languages express the path of motion in the verb (Talmy, 2000b, p. 222). Accordingly, contemporary Chinese is allegedly a satellite framing-dominant language because, in Talmy's terms, it frames the path of motion in a satellite. This is shown in (1) in boldface:

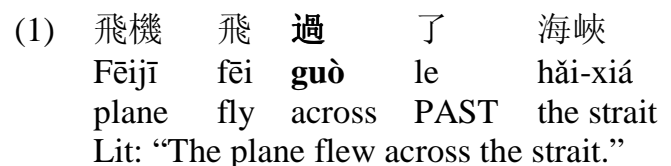

The manner in (1) is expressed by the main verb feei, "fly", and the path is expressed by an element other than a verb, i.e. guò, "across". On the other hand, contemporary Japanese habitually frames the path of motion in the verb and hence is alleged to be a verb-framed language, as exemplified by (2):

$\begin{array}{llll}\text { (2) 太郎 は } & \text { 駅 } & \text { 歩いて行った } \\ \text { Taroo wa eki ni } & \text { aruiteitta } \\ \text { Taroo Top station to } & \text { walk-PAST } \\ \text { “Taroo walked to the station” } & \end{array}$

Talmy's dichotomous typology has been criticised by many scholars in points of detail (see, for example, Matsumoto, 1996; Ramchand \& Folli, 2005; Croft, 2010). Among the critics, Slobin (2004b) and Zlatev and Yangklang (2004) are the most important. They propose a third class: equipollent framing, which seems to apply to languages that have productive verb compounds or serial verb constructions, such as Thai and Chinese.

In fact, the event framing of Chinese has undergone a long-term evolution. From the warring states period (551 B.C. to 479 B.C.) till the unification of Qin (221 B.C.), the Chinese language consisted of a monosyllabic root, to which affixes were attached. From the Han period (202 B.C.), disyllabic word roots appeared, e.g. nominal 
compounds 君子 “jūnzlı”, verbal compounds 杀翏 “shā-lù” and compound particles 鸣 呼 “ $w \bar{u} h \bar{u}$ ”. Finally, serial verb construction appeared. Some data suggest that Old Chinese exhibits verb framing, as illustrated in (3):
(3) 賢良 遂進 xián-liáng suì jìn 而姦邪 并 退 talented excellent then proceed and wicked evil together withdraw "The talented and excellent will then go forwards and the wicked and evil will withdraw." (Hanfezi)

In (3), the semantic component of the path is incorporated in the head verb, i.e. 進 jin; 退 tuì (in boldface). Such data come to resemble Old Japanese, as we can see in (4):
(4) ...那 賀 那加佐麻久 阿佐阿米 能 疑理 爾多多牟 叙... na ga naka-sa-ma ku asa ame no kwiri ni tata-mu zo you GEN cry-RESP-CONJ-NLZR morning rain GEN fog DAT rise-CONJ FOC "your crying is like the rising into fog of the morning rain" (Kojiki 4)

(4) is a telic event, consisting of a combination of [Ground $\mathrm{NP}^{1}+\mathrm{V}$ ]. The path is encoded by the head verb 立たむ tatamu.

This paper brings a diachronic perspective to the study of motion and non-motion events in Old Chinese and Old Japanese. The following two issues are to be discussed:

(a) The vocabulary of Chinese has undergone a long-term grammaticalisation, i.e. many particles which are considered "satellites" in contemporary Chinese bear substantive content in Old Chinese. This inspires us to ponder if verb framing, satellite framing, and equipollent framing coexisted in Old Chinese?

(b) The similarities between Old Chinese and Old Japanese, bearing in mind that both exhibit verb framing.

To serve the above purpose, this paper is mapped out as follows: in section 2, we discuss motion events in Old Chinese, followed by a look at the expressions of the path component. Section 3 is devoted to the event framing of Old Japanese. Finally, section 4 proposes a hypothesis and concludes the paper.

The data for Old Chinese were collected from Analects (論語 700 B.C.), Shi Jing (詩経 1000 B.C.), Mencius (孟子 475 B.C. - 221 B.C.), Xun Zi (荀子 313 B.C. - 238 B.C.), Han Fei Zi (韓非子 281 B.C. - 23 B.C.), Zhan Guo Ce (戰国策 Western Han Dynasty: 206 B.C. - A.D. 24), Shi Ji (史記 104 B.C. - 91 B.C.). The data for Old Japanese were collected from Kojiki Kayō (古事記歌謡, A.D. 712), Nihon Shoki Kayō (日本書紀歌謡, A.D. 720), and Man'yōshū (万葉集, after A.D. 759).

\footnotetext{
${ }^{1}$ NP: noun phrase
} 


\section{Motion event framing in Old Chinese}

\subsection{Definitions of "satellite" and "Ground NP"}

Before we get started, it is worthwhile defining two terminologies, i.e. "satellite" and "Ground NP". According to Talmy:

The satellite to the verb... is the grammatical category of any constituent other than a nominal or prepositional-phrase complement that is in a sister relation to the verb root. The satellite, which can be either a bound affix or a free word, is thus intended to encompass all of the following grammatical forms: English verb particles, German separable and inseparable verb prefixes, Latin or Russian verb prefixes, Chinese verb complements... (Talmy, 2000, p. 222)

A Ground NP appears like a common noun. Nikitina (2008, pp. 186-187) divides the grounds into two types: (a) Container grounds: locations with well-defined boundaries, and often a well-defined entrance/exit, such as rooms, boxes, and buildings; and (b) Area grounds: locations that lack such boundaries, such as forests, neighbourhoods, fields and space.

Crucially, following Talmy (2000), the framing event entails a core schema, which describes the relationship between the Figure and the Ground. This core schema, in Talmy's words, is the Path. Given this, how the path is framed-by the main verb or the satellite to the main verb-appears the most essential point.

\subsection{Previous studies on Old Chinese linguistics}

The key figure in the historical study of Chinese was Bernhard Karlgren, whose reconstruction of the language of the Qieyun rhyming dictionary of A.D. 601 (191526) led to the discovery of the relations between morphology and syntax in Old Chinese. Another dominant figure was Kennedy (The Classical Pronoun Forms ngo and nga, 1956), whose study particularly focuses on tone, stress, and pause. AC Graham (1973) discusses the evolution of the pronoun system and denies the analogy with the Indo-European case system. Other key figures include Chou Fa-kao (Historical Grammar of Ancient Chinese) and Wang Li. In spite of these remarkable previous studies, there have been few attempts made at the study of event framing in Old Chinese. Peyraube contributes to a discussion on Chinese directional complements in Hickmann and Robert's (2006) book Space in Languages. Their short discussion focused on the grammaticalisation of 来 “come”, 去 “go", and 出 “exit". 


\subsection{Motion events in Old Chinese}

In light of the definitions of "satellite" and "Ground NP", we are now in the position of examining the framing behaviours of Old Chinese motion and non-motion events.

\subsubsection{Path expressed by particle [ $v^{\prime} \mathrm{V}$ [pp $P$ NP] $]$}

The following is a motion event from Analects, where a particle expresses the path, i.e. 自 $z \grave{\imath}$ “from”:

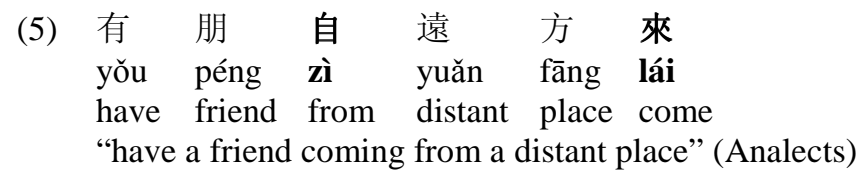

In (5), 来 lái bears a substantive meaning, i.e. "to come". In modern Chinese it has been grammaticalised, holding a deictic meaning, e.g. păo chū lái "run-out-come". Here it is paired with an ablative case marker 自 $z i$ "from", which binds the path and entails a source (yuăn fāng "distant place") function. This motion event, in Talmy's sense, technically exhibits satellite framing.

\subsubsection{Path expressed by verb root [Figure V Ground NP]}

Motion events with the path denoted by verb roots present two types of eventframing pattern. The following piece of data suggests its path lexicalised by a verb root:

（6） 甘茂 亡 秦且之齊

Gān Mào wáng Qín qiě zhī Qí

Gan Mao exile Qin moreover go to Qi

"Gān Mào exile (from) Qín and went to Qî” (Zhanguoce)

(6) is a coordinate clause, denoted by the conjunction 且 "moreover"2. Two motion morphemes are involved, i.e. 亡 wáng and 之 zhī. The first morpheme 亡 wáng is unergative, meaning "exile" and 秦 Qín is a container Ground NP, denoting the SOURCE of wáng “exile”. Thus, syntactically, 亡秦 wáng Qín is like a verb phrase (VP), and licenses the external argument.

\footnotetext{
${ }^{2}$ According to a reviewer of this piece, “亡 .... (且 ) 之 ...” can also be considered as split construction.
} 
The second motion verb $\dot{Z}^{3} z h \bar{l}$ "reach, arrive at", likewise appears to incorporate the container Ground NP 齐 $Q i$, which contributes to the GOAL. Thus, the motion 之 齐 "reaching Qi" is like a VP. The semantic relationships of the motion verbs and the Ground NPs in the two motion events are similar. They both conflate the path into the head verbs and thus suggest verb framing.

The following data, from Xunzi (313 B.C. - 238 B.C.), also has its path framed with a verb root. However, it presents a different framing pattern:

(7) 孔子 $\quad$ 趋 $\quad$ 出
Kǒng ž $\quad$ qū $\quad$ chū
Kǒng zí $\quad$ hurry go out
"Kǒng zǐ
went out in a hurry" (Xunzi)

As far as (7) is concerned, 趋 $q \bar{u}$ denotes the manner of the motion, meaning "hurry up"; 出 chu serves as the path component. Peyraube (2006) points that a coordinate conjunction is available to insert between the two morphemes; thus it can be 趋而出 “hurry up and go out". This syntactic test suggests that the two morphemes, i.e. manner and path, receive an equal semantic as well as syntactic weight. This inspires us to ponder if, as early as 313 B.C. - 238 B.C., equipollent framing already existed. However, such data is not found much, as the path morpheme 出 chi soon gets grammaticalised and behaves like a directional complement.

\subsubsection{Path expressed by complement [ $v^{\prime} \mathrm{V}$ [V-COMP $\left.\left.{ }^{4}\right]\right]$}

Example (8) is a non-motion event from Shi ji (史记 104 B.C. - 91 B.C.), a century later than the Xunzi. 出 $c h \bar{u}$ is the path verb, behaving like a satellite, i.e. a resultative complement rather than a substantive verb as it does in the earlier work:

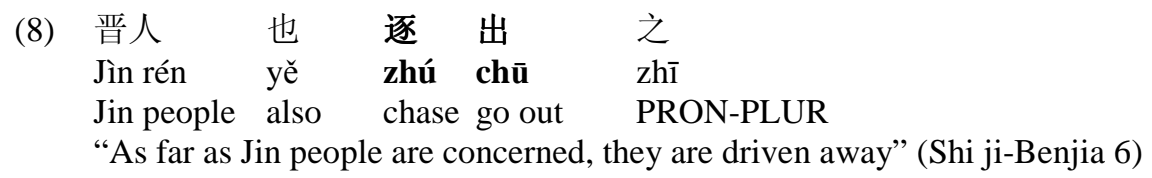

To note, the pronoun 之 zhī co refers to the topic 晋人 Jìn rén, "people of Jìn Land". The cause verb 逐出 zhú-ch" "chase-go out" is composed by a transitive verb V1 逐 zhú, which Li and Thompson (1981) and Lu (1973) refer to as a "displacement verb", and a complement 出 chī.V1 does not imply an accomplishment; it is the second morpheme 出 $c h \bar{u}$ that denotes the result of the action. Obviously, 出 $c h \bar{u}$ here seems to have lost its full lexical meaning, which we suppose to be due to the

\footnotetext{
${ }^{3}$ 之 has many meanings; it could be a pronoun, a grammaticalised nominaliser, or verb, as in this case. The verb usage is frequently found in Old Chinese, with more examples including 辗耕之垄上 [陈涉世 家].

${ }^{4}$ COMP: complement
} 
vocabulary evolution during the Han Dynasty. Crucially, though, the manner morpheme and path morpheme together take the patient 之, i.e. a plural pronoun; they are not bound. The path 出 $c h \bar{u}$ can be replaced by other complements, as long as they denote an accomplishment to the action. Given this, we can assume that it is the first constituent that determines the transitivity of the whole and thus should be viewed as the head. The resultative path component here can be considered framed outside of the verb root. Therefore satellite framing is suggested in this event.

\subsubsection{Path expressed by preverb [ ${ }^{\prime} \mathrm{V}$ [PREV $\left.\left.{ }^{5}-\mathrm{V}\right]\right]$}

Furthermore, it is a very productive pattern that motion verbs are preceded and modified by potential preverbs in Old Chinese, as shown in (9):

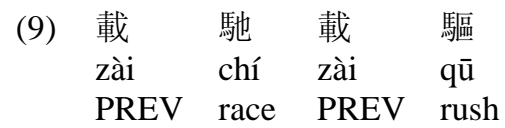

“(I) was racing along and (I) was rushing along” (Shi Jing)

There are two motion verbs, i.e. 馳 $c h i$ 驅 $q \bar{u}$. The path is not borne by the head verb but a non-head preverb, i.e. 載 zài, which denotes a progressive reading of the motion.

\subsubsection{Path expressed by incorporated noun [ $\mathrm{v}^{\prime} \mathrm{V}$ [NP [N-V]]]}

Path can be further denoted by an incorporated noun, as exemplified by (10):

$\begin{array}{lllllll}\text { (10) 孔雀 } & \text { 東 } & \text { 南 } & \text { 飛 } & \text { 五 里 } & \text { 一 } & \text { 徘徊 } \\ \text { kǒng què } & \text { dōng } & \text { nán } & \text { fēi } & \text { wǔ lǐ } & \text { ȳ̄ } & \text { pái-huái } \\ \text { peacock } & \text { east } & \text { south } & \text { fly } & \text { five league } & \text { one } & \text { waver }\end{array}$

"South-east fly the peacocks, every five leagues they waver" (Kongque Dongnan Fei)

The directional noun 东南 dōng nán "southeast" functions as a manner or an adverb of the motion verb 飛 $f \bar{e} i$ "fly", meaning "towards the southeast". In this case, an incorporated noun denotes the satellite in relation to the verb. Moreover, it also appears that, in the Late Han Dynasty, a bisyllabic-morpheme verb emerges, e.g. 徘徊 pái-huái. The two morphemes are both bound, and are considered a rhyming compound 畳韻詞 (see Chung, 2006, pp. 138-139). Incorporating Talmy’s (2000, pp. 35-36) discussion of "translational motion", pái-huái "to wander" should be considered a self-contained motion. Therefore, such data is excluded, despite it providing a piece of evidence for potential equipollent framing in Old Chinese.

\footnotetext{
${ }^{5}$ PREV: preverb
} 


\subsection{Summary}

This section has been devoted to event framing in Old Chinese and the data have shown a degree of intralinguistic variation. Old Chinese displays three framing strategies: verb framing, satellite framing, and equipollent framing. This result fails to justify our assumption on the development of event-framing patterns, i.e. that satellite framing may appear later than verb framing (in fact, its first appearance is as early as 700 B.C., in Analects). There is therefore no trend suggesting the development of Chinese event framing shifting from verb framing towards satellite framing to equipollent framing; instead, they co-exist in Old Chinese. However, we can assume verb framing was the main framing strategy before the syntactical evolution that takes place in the Han period. Moreover, it has been observed that five constituents contribute to the path: (a) particle, (b) verb root, (c) complement, (d) preverb and (e) incorporated noun.

\section{Event framing in Old Japanese}

In this section, the discussion focuses on Old Japanese. Contemporary Japanese is typically considered to be verb framing (Talmy, 2000, p. 222) and such a strategy is also seen in Old Japanese. Furthermore, the path is expressed by a variety of lexical resources.

It is worth mentioning that, before the development of the purely phonetic script hiragana (in the late 800s A.D.), the Japanese employed Chinese characters to represent on paper vernacular Japanese. Kojiki, the oldest extant chronicle in Japan, is written in a mixed Chinese-Japanese script, which is termed 変体漢文 hentai-kanbun "variant Chinese". Variant Chinese refers to a script which is a combination of Chinese and a phonetic transcription of Japanese. Nihon Shoki Kayō is the second oldest book of classical Japanese. It was written in classical Chinese, due to it being the official language at that time. Man'yōsh $\bar{u}$ is the oldest collection of Japanese poetry and was written in man'yoggana, where three patterns of the borrowing of Chinese characters are used, i.e. solely borrowing semantic meaning, solely borrowing phonological value, and borrowing both semantic and phonological values.

\subsection{Verb framing in Old Japanese}

In light of the Old Japanese data, we are now in the position to examine the framing strategies of motion and non-motion events. To begin with, we explore a variety of lexical resources that denote the path. 


\subsubsection{Path denoted by prefixes [ $v^{\prime} \mathrm{V}$ [PREF-V]]}

First, the path can be expressed by a prefix on the verb. The following example provides a combination of [Ground NP + Prefix + Manner $]^{6}$ :

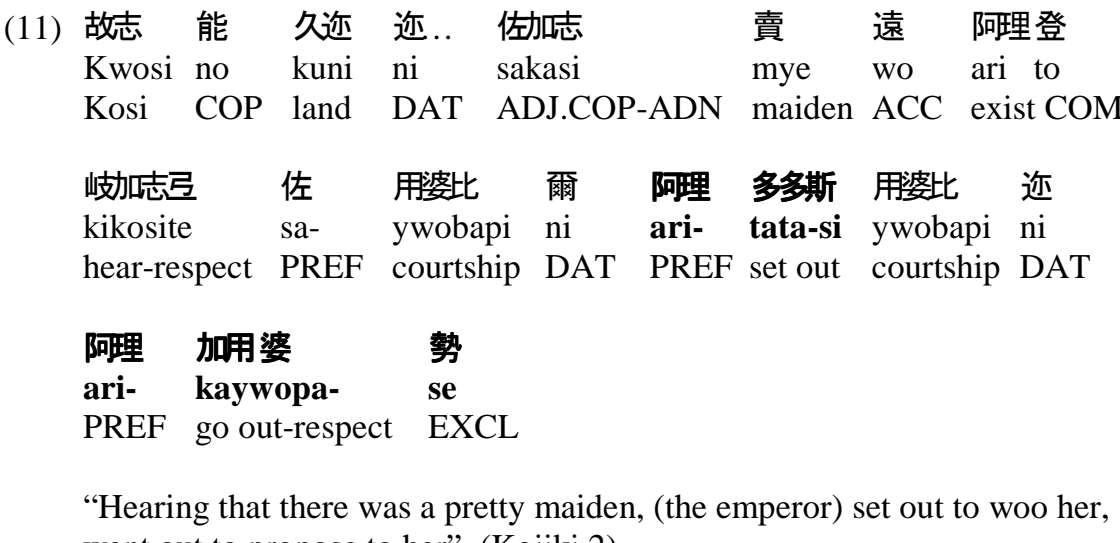
went out to propose to her" (Kojiki 2)

The motion verbs，あり立たし aritatasi; あり通はせ arikaywopase are in respectful forms, meaning "set out". The paths of motion verbs 立つ; 通字 are denoted by the potential prefix あり. The path expression is telic, since they imply the arrival at the destinations, i.e. the Ground NP 婚ひ. Given this, verb framing is exhibited in the two motion events.

\subsubsection{Path denoted by auxiliaries [ $\left.v^{\prime}[[\mathrm{V}-\mathrm{AUX}] \mathrm{V}]\right]$}

Second, the expression of the path can be denoted by an auxiliary on the verb, as shown in (12):
(12) 吾 妹子夢見 来... waga imokwo wo ime ni mi-ye- ko to my dear love dream DAT see-PASS- come.IMP COMP "praying: 'my dear love, come (let me see) appear to me in my dreams"” (MYS 12.3128)

This is an optative expression. Following Nikitina's (2008: 186) insight, 夢 ime can be assumed as a container Ground NP. In the motion 見来 mi-ye-ko, the path is expressed via an auxiliary "-ye-", which denotes a passive reading. Incorporating this, the path information is lexicalised in the verb as the head, which thus suggests verb framing.

\footnotetext{
${ }^{6}$ The analysis and glossing of Old Japanese examples follow Frellesvig (2010).
} 


\subsubsection{Path denoted by verb compounding [ $\left.\mathbf{v}^{\prime} \mathrm{V}[\mathrm{V}-\mathrm{V}]\right]$}

Path can be further expressed by verb compounding, as shown in (13):

$\begin{array}{cllllllll}\text { (13) …阿賀 } & \text { 淤富久爾 } & \text { 奴斯 } & \text { 那 } & \text { 許曾 } & \text { 波 } & \text { 遠 } & \text { 迩 } & \text { 伊麻世 } \\ \text { a ga } & \text { opo-kuni } & \text { nusi } & \text { na } & \text { koso } & \text { pa } & \text { wo } & \text { ni } & \text { imase } \\ \text { I-GEN } & \text { great-country } & \text {-ruler } & \text { you } & \text { FOC } & \text { TOP } & \text { man } & \text { COP } & \text { exist.RESP } \\ \text { 婆 } & \text { 宇知 } & \text { 微梳 } & & \text { 斯麻 } & \text { 能 } & \text { 佐岐邪岐 } & \text { 加岐 } & \text { 微流 } \\ \text { ba } & \text { uti } & \text { mwiru } & \text { sima } & \text { no } & \text { sakizaki } & \text { kaki } & \text { mwiru } \\ \text {-because } & \text { PREF- } & \text { move.about } & \text { island } & \text { GEN } & \text { tip-tip } & \text { PREF- } & \text { move.about }\end{array}$

$\begin{array}{lllll}\text { 伊蘇 } & \text { 能 } & \text { 伤枝 } & \text { 㵀口 } & \text { 受 } \\ \text { iswo } & \text { no } & \text { saki } & \text { oti- } & \text { zu } \\ \text { beach } & \text { GEN } & \text { tip } & \text { fall } & \text { NEG }\end{array}$

"Oh, my divine Yachipoko, the ruler our country, since you are a man, you move about on all the islands; move about on each beach, without exception" (Kojiki 5)

The above two motion events consist of a combination of [Area Ground NP + V$\mathrm{V}^{8}$ ], i.e. うち廻る uti-mwiru; かき廻る kaki-mwiru. They are atelic directed motion events. The path is encoded by the head verb 廻る; the manner components are expressed by prefixes on the verbs, i.e. うち uti; かき kaki. The motion events display verb framing.

In fact, the employment of verb compounding is quite often found in the Man'yoshu and (14) provides another example:

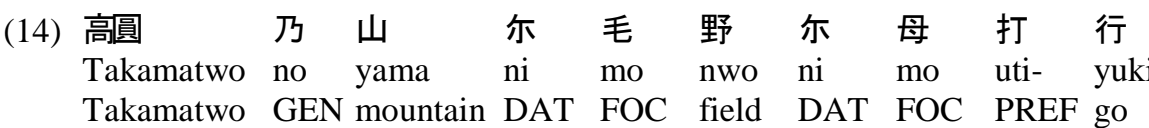

$\begin{array}{llll}\text { 而 } & \text { 遊 } & \text { 往 } & \text { 杼... } \\ \text { te } & \text { aswobi- } & \text { aruke } & \text { do. } \\ \text { GER } & \text { play } & \text { walk } & \text { CONC }\end{array}$

"Though go and wander around the mountain and fields of Takamato as I like ..." (MYS 8.1629)

A salient property of this motion event lies in that it involves two verbal forms: a main verb, denoted by V2 徃 aruku “walk", and an adverbial verb denoted by V1 遊 aswobu "play". The motion is not telic as there is no destination. Such a pattern appears quite productive in Old Japanese.

Furthermore, in the following verb-framing event, the path information is encoded by the head verb, with manner indicated by an adverbial verb:

\footnotetext{
${ }^{8} \mathrm{~V}-\mathrm{V}$ : verb compounding
} 


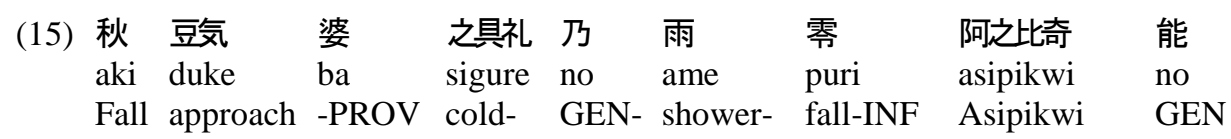

$\begin{array}{lllllllll}\text { 夜麻 } & \text { 能 } & \text { 許奴礼 } & \text { 波 } & \text { 久礼奈為 } & \text { 爾 } & \text { 仁保比 } & \text { 知礼 } & \text { 止毛 } \\ \text { yama } & \text { no } & \text { konure } & \text { pa } & \text { kurenawi } & \text { ni } & \text { nipopi } & \text { tire } & \text { domo } \\ \text { mountain } & \text { GEN } & \text { tree-tops } & \text { TOP } & \text { crimson } & \text { COP } & \text { smell-INF } & \text { go bare } & \text {-CONC }\end{array}$

"When autumn approaches with cold showers, the mountain tree-tops turn red and soon go bare" (MYS 18.4111)

To note, in contemporary Japanese におい means "smell", but in the time from Old Japanese to pre-modern Japanese nipopi denotes the meaning "beautiful"; here, nipopi plays the role of modifying the manner of the motion tiru.

\subsection{Equipollent framing in Old Japanese}

So far, it seems that verb compounding plays the most significant role in motion events in Old Japanese. The following non-motion event, however, which is again denoted by verb compounding, is different:

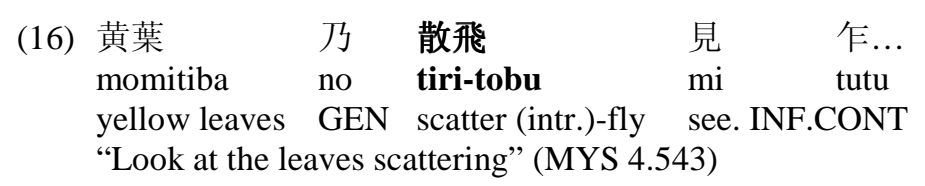

The compound 散飛 tiritobu is in a relative clause. It is composed by two nonscalar change motion morphemes, i.e. V1 tiru "scatter" and V2 tobu "fly". The two morphemes have the same meaning and scalar properties. They are considered a synonymous lexicon. The events represented by V1 and V2 are classified as the same categories (i.e. both of them are motion events). Given this, syntactically and semantically, the two motion morphemes seem to receive an equipollent weight. Therefore, equipollent framing is tentatively suggested.

Another piece of evidence for this framing pattern is provided in (17):

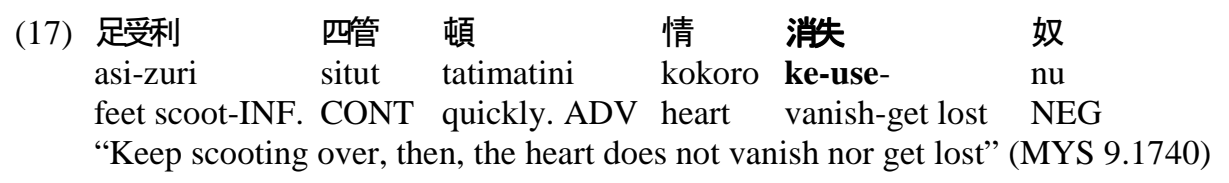

The two morphemes in the non-motion event keuse "vanish-get lost" have the same meaning and scalar properties, i.e. both V1 消“vanish" and V2 失 "get lost" are unaccusative verbs. Semantically, the two morphemes are weighted equally. Syntactically, the compound is followed by a negative auxiliary 奴 $n u$. As stated above, Man'yōshū was written in man'yōgana, a form in which Chinese characters are employed to represent Japanese. Hence, the negation of Old Japanese is denoted by an 
independent word rather than inflectional auxiliary attached to V2, as in contemporary Japanese. Therefore, morphologically, the two morphemes are ranked as equipollent and are framed coordinately. Given this, we may safely conclude that Old Japanese could possibly exhibit equipollent framing.

\subsection{Satellite framing in Old Japanese}

Furthermore, the following data inspires us to ponder if satellite framing also perhaps exists in Old Japanese. In this non-motion event, the path is expressed by verb compounding, which consists of a cause verb V1, denoting an action and a stative verb $\mathrm{V} 2$, expressing a state or the result of an action:

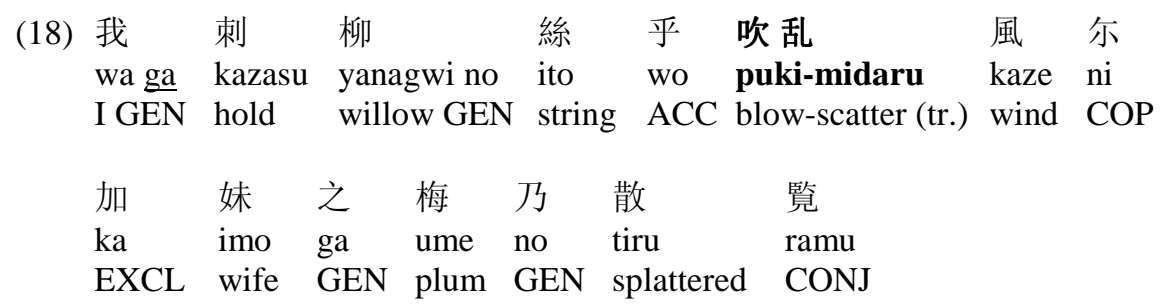

"The wind that blows and scatters the willow that I am holding, oh, my wife's plum must also be scattered around at the moment" (MYS 10.1856)

The compound 吹乱 puki-midaru "blow-scatter" is composed by an unaccusative verb and a transitive verb. V1 puki "blow" denotes the cause of the motion and V2 contributes to the result midaru "scatter". A verb weakening is seen in the morpheme 乱 midaru "scatter". As a result, it should be acknowledged as a resultative complement. Given this, we argue this non-motion event lexicalises the path information by a resultative complement rather than a head verb. Crucially, such a resultative complement behaves like a satellite, and this inspires us to tentatively propose that satellite framing does indeed potentially exist in Old Japanese.

\subsection{Summary}

In this section, discussion has focused on the event framing of motion and nonmotion events in Old Japanese. The path in is expressed via three means, i.e. prefix, auxiliary, and verb compounding. Among them, verb compounding appears to play the most significant role. Verb framing appears to be the main framing strategy. Interestingly, satellite framing and equipollent framing have also been found in the data. This phenomenon suggests that Old Japanese displays a wider variety of framing strategies than contemporary Japanese. We thus ponder whether such variety is possibly down to the distinct writing systems employed in Old Japanese, e.g. 変体漢文 hentai-kanbun “variant Chinese”, 万葉がな man'yōgana etc. Along with the emergence of the purely phonetic script hiragana in the late 800s A.D., "variant 
Chinese" and man'yoggana gradually disappear, with the syntactic similarities between Chinese and Japanese declining. When we come to today, they have diverged so far as to now belong to different language families.

\section{Conclusion}

This paper has brought a diachronic perspective to an investigation of event framing in Old Chinese and Old Japanese. Contrary to our assumptions, it seems there is no unidirectional shift of event-framing strategy in Old Chinese or Old Japanese. Path can be denoted by a variety of lexical resources. Particle, preverb, incorporated noun, prefix, auxiliary, verb root, verb compounding and complement have all been observed to express the path in Old Chinese and Old Japanese. This variety in the expressions of path give rise to various event-framing patterns. Three event-framing patterns, i.e. satellite framing, verb framing, and equipollent framing, seem to co-exist in both Old Chinese and Old Japanese. Table $1^{9}$ gives a comparison of the distinct event-framing strategies according to various linguistic resources in each language. Table 2 provides the linguistic transformation that gives rise to the change of framing patterns in the two languages.

Table 1: Event-framing strategies in line with the lexical and morph syntactic resources

\begin{tabular}{|l|l|l|}
\hline Lexical resources & Old Chinese & Old Japanese \\
\hline Particle & $s f$ & $\emptyset$ \\
\hline Incorporated NP & $s f$ & Not saliently used \\
\hline Prefix & $\varnothing$ & $v f$ \\
\hline Auxiliary & $\varnothing$ & $v f$ \\
\hline Verb compounding & $\begin{array}{l}\text { Rare but } \\
s f ; e f\end{array}$ & $\begin{array}{l}\text { Productively exist } \\
v f ; \text { ef; } s f\end{array}$ \\
\hline Preverb & $v f$ & $\varnothing$ \\
\hline Complement & Rare but $s f$ & Rare but $s f$ \\
\hline \hline
\end{tabular}

${ }^{9} \mathrm{~s}$ f: satellite framing, e f: equipollent framing, v f: verb framing 
Table 2: Linguistic transformation of lexical and morph syntactic resources

\begin{tabular}{||l|l|l||}
\hline Lexical resources & Modern Chinese & Modern Japanese \\
\hline \hline Particle & Remain & Exist \\
\hline Incorporated NP & Declined & Exist \\
\hline Prefix & $\begin{array}{l}\text { Transformed to } \\
\text { verb compound }\end{array}$ & Remain \\
\hline Auxiliary & Declined & Remain \\
\hline Verb compounding & Productively exist & Productively exist \\
\hline Preverb & Declined & $\emptyset$ \\
\hline Complement & Productively exist & Declined \\
\hline
\end{tabular}

Furthermore, this paper argues that Talmy's typology, as well as those of other linguists (Slobin, 2004b; Zlatev \& Yangklang, 2004), are not real semantic typologies of crosslinguistic variation. The distinct event-framing patterns we see both intralinguistically and crosslinguistically are based on the diversity of lexical resources available in terms of motion/non-motion event framing and on the preferences for event-encoding options which rest on the selection of different lexical resources.

\section{References}

Beavers, J. (2008). On the nature of goal marking and delimitation: evidence from Japanese. Journal of Linguistics, 44, 183-316.

Chen, L., \& Guo, J. (2009). Motion events in Chinese novels: Evidence for an equipollentlyframed language. Journal of Pragmatics, 41, 1749-1766.

Chou, F. (1962). A Historical Grammar of Ancient Chinese, Part II: Morphology. The Institute of History and Philology, Academia SinicPastecial Publications No. 39, Taipei.

Croft, W., Barðdal, J., Hollmann, W. B., Sotirova, V., \& Taoka, C. (2010). Revising Talmy's typological classification of complex event constructions.. In Boas, H. C. (Ed.), Contrastive Studies in Construction Grammar (pp. 201-235). Amsterdam: John Benjamins.

Folli, R., \& Ramchand, G. (2005). Prepositions and results in Italian and English: An analysis from event decomposition. In H. Verkuyl, A. van Hout \& H. de Swart (Eds.), Perspectives on Aspect (pp. 1-20). Dordrecht: Springer.

Frellesvig, B. (2010). A History of the Japanese Language. Cambridge: Cambridge University Press.

Frellesvig, B., Horn, S. W., Russell, K. L., \& Sells, P. (2010). Verb semantics and argument realization in pre-modern Japanese: A preliminary study of compound verbs in Old Japanese. Gengo kenkyū, 138, 25-65.

Graham, A. C. (1973). China, Europe, and the Origins of Modern Science: Needham's The Grand Titration. In S. Nakayama \& N. Sivin (Eds.), Chinese Science. Explorations of an Ancient Tradition (pp. 45-69). Cambridge: MIT Press. 
Hickmann, M. \& Robert, S. (2006). Space in Languages: Linguistic Systems and Cognitive Categories. Amsterdam; Philadelphia: John Benjamins Publishing Company.

Kageyama, T. (1999). Word formation. In N. Tsujimura (Ed.) The handbook of Japanese linguistics (pp. 297-325). Oxford: Blackwell Publishers.

Karlgren, B. (1933). Word families in Chinese. Bulletin of the Museum of Far Eastern Antiquities, 12, 1-471.

Kennedy, G. A. (1956). Zai lun wu wo (The Classical Pronoun Forms ngo and nga). Bulletin of the Institute of History and Philology, Academia.

Li, C. N. \& Thompson, S. A. (1981). Mandarin Chinese: A functional reference grammar. University of California Press.

Lu, J. H.-T. (1973). The verb-verb construction with a directional complement in Mandarin. Journal of Chinese Linguistics, 1, 239-255.

Matsumoto, Y. (1996). Complex predicates in Japanese: a syntactic and semantic study of the notion "word". Stanford Center for the Study of Language and Information.

Matsumoto, Y. (1996). Kuukan no Gengo Hyugen to Sono Kakuchoo (Linguistic expressions of spatial motion and their extensitions). Kuukan to Idou no Hyogen. Kenkyuusha shuppan, 126-229.

Nikitina, T. (2008). Pragmatic Factors and Variation in the Expression of Spatial Goals: The Case of into vs. in. In A. Asbury, J. Dotlačil, B. Gehrke, \& R. N (Eds.), Syntax and Semantics of Spatial P (pp. 175-209). Amsterdam: John Benjamins.

Peyraube, A. (2006). Motion events in Chinese: A diachronic study of directional complements. In M. Hickmann \& S. Robert (Eds.), Space in Languages: Linguistic systems and cognitive categories (pp. 121-135). Philadelphia: John Benjamins.

Slobin, D. I. (1996). Two ways to travel: Verbs of motion in English and Spanish. In M. S. Shibatani \& S. A. Thompson (Eds.), Grammatical constructions: Their form and meaning (pp. 195-219). Oxford: Oxford University Press.

Slobin, D. I. (2000). Verbalized events: a dynamic approach to linguistic relativity and determinism. In S. Niemeier \& R. Dirven (Eds.), Evidence for linguistic relativity (pp. 107-138). Amsterdam/Philadelphia: John Benjamins.

Slobin, D. I. (2004a). How people move: Discourse effects of linguistic typology. In C. L. Moder \& A. Martinovic-Zic (Eds.), Discourse across languages and cultures (pp. 195210). Amsterdam: John Benjamins.

Slobin, D. I. (2004b). The many ways to search for a frog: Linguistic typology and the expression of motion events. In S. Strömqvist \& L. Verhoeven (Eds.), Relating Events in Narrative (Vol. 2, pp. 219-257). Mahwah, NJ: LEA.

Slobin, D. I. (2006). What makes manner of motion salient? Explorations in linguistic typology, discourse, and cognition. In M. Hickmann \& S. Robert (Eds.), Space in languages: Linguistic systems and cognitive categories (pp. 59-81). Amsterdam: John Benjamins.

Talmy, L. (1975). Semantics and syntax of motion. In J. Kimball (Ed.), Syntax and Semantics (Vol. IV, pp. 181-238). New York: Academic Press.

Talmy, L. (1985). Lexicalization patterns: semantic structure in lexical forms. In T. Shopen (Ed.), Language typology and syntactic description, vol. 3: Grammatical categories and the lexicon (pp. 36-149). Cambridge: Cambridge University Press.

Talmy, L. (1991). Path to realization: A typology of event integration. Buffalo Working Papers in Linguistics, 91-01, SUNY, Buffalo, 147-187.

Talmy, L. (2000a). Toward a cognitive semantics, Vol. I: Concept-structuring systems. Cambridge, Mass.: MIT Press. 
Talmy, L. (2000b). Toward a cognitive semantics, Vol. II: Typology and process in concept structuring. Cambridge, Mass.: MIT Press.

Wang, L. (1957-58). Hanyu shi gao. Beijing: Kexue yuan.

Zlatev, J. \& P. Yangklang. (2004). A third way to travel. The place of Thai in motion-event typology. In S. Strömqvist \& L. Verhoeven (Eds.), Relating Events in Narrative:

Typological and Contextual Perspectives (pp. 159-190), Mahwah: Lawrence Erlbaum Associates.

\title{
Grammatical Terms
}

$\begin{array}{llll}\text { ACC } & \text { accusative } & \text { IMP } & \text { imperative } \\ \text { ADV } & \text { adverb } & \text { INF } & \text { infinitive } \\ \text { COMP } & \text { complementiser } & \text { NEG } & \text { negative } \\ \text { CONC } & \text { concessive } & \text { NLZR } & \text { nominalizer } \\ \text { COND } & \text { conditional } & \text { PASS } & \text { passive } \\ \text { CONJ } & \text { conjectural } & \text { PLUR } & \text { plural } \\ \text { CONT } & \text { continuous } & \text { PREF } & \text { prefix } \\ \text { COP } & \text { copula } & \text { PRON } & \text { pronoun } \\ \text { DAT } & \text { dative } & \text { PROV } & \text { provisional } \\ \text { EXCL } & \text { exclamatory } & \text { RESP } & \text { respect } \\ \text { FOC } & \text { focus } & \text { TOP } & \text { topic } \\ \text { GER } & \text { gerund } & & \end{array}$

\section{Chinese data source}

\author{
論語 Analects (700 B.C.) \\ 詩経 Shi Jing (1000 B.C.) \\ 孟子 Mencius (475 B.C. -221 B.C.) \\ 荀子 Xun Zi (313 B.C. -238 B.C.) \\ 韓非子 Han Fei Zi (281 B.C. -23 B.C.) \\ 戰国策 Zhan Guo Ce (206 B.C. - A.D. 24) \\ 史記 Shi Ji (104 B.C. - 91 B.C.)
}

\section{Japanese data source}

万葉集 Man'yōshū (A.D. 759)

古事記歌謡 Kojiki Kayō (A.D. 712) 